\title{
Disaster Studies at 50: Time to Wear Bifocals?
}

\author{
Ben Wisner
}

\begin{abstract}
Other writers have cataloged the many contributions to understanding and practice that disaster studies have produced over the years, many of them, and the earliest, coming from sociology. The Disaster Research Center at the University of Delaware was founded in 1963 by, and is still inhabited by sociologists, but has embraced an interdisciplinary approach over time, including core and affiliated faculty from English, history, political science, civil engineering, and environmental policy). My thoughts in this essay are not confined to the DRC's corpus of work, but 'disaster studies' more broadly defined below. This said, the roots of disaster studies in sociology are deep, the classic Ur-source being an unpublished PhD study of the 1917 explosion in Halifax, Nova Scotia. This disaster continues to be a source of continuing research that provide lessons for our time. My own essay will mention some of these contributions, and they are truly something to celebrate; however, the central theme I will emphasize is what has been missed and could be added to the research agenda over the next decade or so. I employ an optical metaphor that has as much to do with philosophy of science ('vision' and Mao's famous question, 'Where do ideas come from?') as it does with optics, optometry and the detailed application of methods at micro and macro scale. The lens is a remarkable human invention. Glass shaped and polished in one way opened up the microscopic world. Treated in another, the lens gave us the telescope. I will argue that politics - the creation, use and maintenance of power to influence other people and to control space and resources - has been a largely missing raw material, like glass, from which disaster studies could shape lenses for its own tools of inquiry. Consideration of power has not been totally missing. Yet lenses fashioned from an understanding of power have not been used sufficiently in a number of critical areas of research.
\end{abstract}

Keywords Disaster research · Disaster studies · Theories of disaster

\footnotetext{
B. Wisner $(\triangle)$

Institute for Risk and Disaster Reduction, University College London, London, UK
} 


\section{Introduction}

Other writers have cataloged the many contributions to understanding and practice that disaster studies have produced over the years, many of them, and the earliest, coming from sociology. My own essay will mention some of these contributions, and they are truly something to celebrate; however, the central theme I will emphasize is what has been missed and could be added to the research agenda over the next decade or so. I employ an optical metaphor that has as much to do with philosophy of science ('vision' and Mao's famous question, 'Where do ideas come from?') as it does with optics, optometry and the detailed application of methods at micro and macro scale. The lens is a remarkable human invention. Glass shaped and polished in one way opened up the microscopic world. Treated in another, the lens gave us the telescope. I will argue that politics - the creation, use and maintenance of power to influence other people and to control space and resources - has been a largely missing raw material, like glass, from which disaster studies could shape lenses for its own tools of inquiry. Consideration of power has not been totally missing (Pelling and Dill 2010; Anderson 2011; Mascarenhas and Wisner 2012; Guggenheim 2014; Tierney 2014). Yet lenses fashioned from an understanding of power have not been used sufficiently in a number of critical areas of research.

My argument is that mainstream disaster studies ${ }^{1}$ (DS) has had problems with both near and distance vision. It has often ignored or misunderstood processes at the highly local, micro scale as well as processes unfolding at the global, macro scale. Like many 50 year olds, DS needs to look again with the aid of bifocals. The lens needed to correct both near and far sight as well as astigmatisms and distorting conditions is more often than not a political lens. Along side the microscope and telescope, humble spectacles can clarify vision and improve acuity.

In particular, I will argue that DS has missed the depth, complexity and utility of local knowledge, coping and self-protection ('autonomous adaptation' in the language of climate change scholarship and practice - Smit et al. 2000; Füssel and

\footnotetext{
${ }^{1}$ I define disaster studies (DS) as a broad interdisciplinary attempt to understand the causes and consequences of events that cause sufficient harm and loss that assistance is required from people and/ or institutions unaffected, whatever size of the group and area affected (a few households in a neighborhood, in the case of urban arson fire to multiple countries in a region of the world in the case of the Zika virus epidemic). DS is not a single, unified epistemic community, rather a series of partly overlapping and intermittently interacting ones that include research and training nodes within established disciplines: sociology, geography, anthropology, political ecology, political science, economics, development studies, epidemiology and public health. In its outreach, advocacy and policy advisory role, DS comes closer to being a univocal community of practice, as witness global consensus-building and lesson learning efforts such as the Sphere Project (http://www. sphereproject.org/) and the Tsunami Evaluation Coalition (http://www.alnap.org/TEC). In this essay I focus on English language literature from these overlapping disciplines. DS has taken different trajectories in other parts of the world, especially Spanish speaking Latin America, where a similarly wide range of disciplinary professionals have interacted with officials of their countries' government civil protection institutions (see http://www.la-red.org/ and for core publications by Andrew Maskrey, Gustavo Wilches-Chaux, Allan Lavell and many others http://www.la-red.org/ public/).
} 
Klein 2006). In addition, with significant exceptions, ${ }^{2}$ DS has also failed to take seriously the political dimension at local scale: the interaction and struggle over power, decision and choice among state, non-state actors and citizens. Turning to macro issues, I will argue that preoccupation with so-called disaster risk reduction (DRR) has left little intellectual (and political) space for addressing disaster risk creation: how business-as-usual economic, social and political life under conditions of globalization creates and distributes risks. Secondly, I will suggest that application of a political lens helps DS investigate the limits of risk governance. A third problem with DS's long range vision concerns new, emergent, trans-boundary and existential risks and the complex ways that governments, corporations, international institutions, the media and citizens understand and respond to these risks.

\section{Near Vision}

\section{Beyond 'Perception' and 'Participation'}

Assessed against the technocratic, hazard-focused paradigm that DS inherited from the Cold War, research into people's perception of hazards and risk was a huge step forward (Burton et al. 1978). Early work by sociologists demonstrated that people behaved in rational and predictable ways in extreme situations (Quarantelli 1954, 1960; Wenger and Parr 1969; Dynes 1970; Quarantelli and Dynes 1972) and that there were many persistent myths about human behavior in disasters. Likewise, the study of emergent organization following disaster and the potential for community involvement in disaster planning underpinned such innovative government programs as US Federal Emergency Management Agency's (FEMA) Project Impact (Drabek 1987; Stallings and Quarantelli 1985). At the international scale, 'community participation' in disaster risk reduction (DRR) became a watchword from midway through the International Decade for Natural Disaster Reduction (1990-1999), with governments and inter-governmental organizations finally catching up to pioneering researchers and innovative non-governmental organizations (NGOs) in this regard (Maskrey 1989; Anderson and Woodrow 1989).

However, no sooner was the catch phrase 'community participation' widely circulating, than researchers found that involvement of residents and risk bearers could take many forms, some involving quite superficial engagement and others much greater. Recalling Arnstein's (1969) so-called ladder of citizen participation, local participation often was found to be a means to ends pre-conceived by external agents. Wisner (1988) juxtaposed such instrumental participation with transformative forms to be found near the top of such a 'ladder' that involved local decisionmaking and control over resources. Cooke and Kothari (2001) collected evidence

\footnotetext{
${ }^{2}$ Exceptions include Bates and Peacock (1987), Nigg and Tierney (1993), Bolin and Stanford
} (1998), Enarson (2001), Enarson and Fordham (2001), and Grineski et al. (2007). 
that the discourse of participation can serve in a variety ways to control and constrain local autonomy and, in effect, become a 'new tyranny'.

Valuable as such research has been, the human beings who 'perceive', 'behave' and 'participate' remained objects of study, not subjects. The interiority and intentionality of people's experience were seldom the starting point. There was no attempt to develop a phenomenology of disaster risk. People's risk perceptions were juxtaposed to 'correct' scientific views and used to design public information campaigns or catalogued as cultural phenomena by anthropologists. Just as clinical medicine assesses cardiac function of an individual or the immunization status of populations, DS assessed and even attempted to quantify the vulnerability of people to hazards and their capacity to cope (Birkmann 2013; Wisner 2016). Generally these 'vulnerable people' (often schematized and taxonomized as 'vulnerable groups' - children, older people, people living with disabilities) were still only objects of study, not agents of their own history. Such work did not identify ways to open up political and social space within which local residents were encouraged to assess their own vulnerability and develop their capabilities. ${ }^{3}$

Researchers focused carefully, accurately and usefully on local knowledge as well as on perception. But the focus was also too narrow. Yes, people know things, but they also have intentions. They improvise and innovate, cooperate and compete. In localities, people perceive and prioritize risk from the quotidian point of view. Larger hazards may be on their radar but are mixed with 'everyday risks' that include social and economic threats. ${ }^{4}$ It was important to demonstrate the existence of very large repertoires of local knowledge people have: for example, more than 75 options for coping with drought known by farmers in semi-arid Kenya (Smucker and Wisner 2008). However, such knowledge seldom played a role in negotiations among residents, government officials or, until recently, non-governmental development partners (Wisner 2010; Hewitt 2012; Mercer 2012).

The big question, and a continuing challenge for DS, is whose knowledge counts, indeed, 'whose reality counts' (Chambers 1999, 2002, 2008). Just as there is a ladder of participation, or degrees of engagement ranging from nominal consultation through fully devolved decision-making, local knowledge can be approached in many ways. Local knowledge - say vernacular terminology for weather phenomena or soil types - may simply be cataloged by external experts or authorities for purposes of better translating their own pre-conceived disaster risk messages (Wisner 2010). In such cases, hazards and risks have been pre-defined by agencies and experts. Rarely do government or NGO staff accept local stakeholders' definitions

\footnotetext{
${ }^{3}$ The distinction between capacity and capability is critical. In the context of disaster risk, the former refers to a repertoire of behaviours available to individuals for reducing loss and damage and for rapid recovery (Wisner et al. 2004). Capability is more than a behavioural repertoire, referring more broadly to expression of intellectual, social and emotional potentials that combine to allow a person to define and to strive toward goals including, but not limited to, reduction of loss and damage (Wisner 2016, drawing upon Nussbaum 2011; Sen 2005).

${ }^{4}$ See Frontline (http://www.gndr.org/programmes/frontline-programme.html), a methodology designed to capture these perceptions/ priorities and to work with them together with partners at various scales.
} 
of priority threats as a basis for action planning and programming. This is particularly true when local priorities diverge from official expectations. For instance, during the pilot test of the Frontline methodology mentioned in the footnote above, residents of a hamlet on the side of an active volcano insisted that the greatest threat they faced was lack of water (Gibson and Wisner 2015).

\section{Beyond 'Top-Down' and 'Bottom-Up'}

A logical and practical consequence of growing attention to perception, participation and local knowledge is the distinction in planning and public administration between 'top-down' and 'bottom-up'. These are, of course, two extreme ends of a continuum of states describing the relationship between government or NGOs and local residents at a point in time. 'Top' refers to centralist, bureaucratic and usually technocratic goal setting and resource mobilization to achieve goals. Levels of 'acceptable' risk are often defined in this way by regulators. 'Bottom' refers to citizens and their formal and non-formal institutions. In the course of the twentieth century there has been increasing demand by citizens for a voice in determining 'acceptable' risk, among other important decisions, and a role in determining how resources are used to implement such decisions (Jasanoff 1986; Leiss and Chociolko 1994; Munzara and Benn 2014). Decentralization, devolution and informality characterize this end of the continuum.

Social science has studied risk governance as an outcome of the interaction of 'top' and 'bottom' as well as 'expert' and 'lay person' along this continuum (Wisner 1995; Kelman and Mercer 2014). Also studied have been the phenomena of 'learned helplessness' (Freire 1973; White 2008), dependency ${ }^{5}$ (Harvey and Lind 2005; Bartle 2012), resistance (Scott 1987, 2010) and 'exit' (Hirschman 1970) that can result from top-down programs that attempt to control people, even for purposes of uplift, betterment and community development, or, indeed disaster risk reduction.

Important as recognition of the 'top-down' versus 'bottom-up' continuum is, DS's near vision is also faulty in this case. Insufficient attention has been paid to struggle over power, decision and choice among government departments, among non-state actors and among groups of citizens (Wisner and Haghebaert 2006; Thompson 2012). The 'top' often ends up fragmented and fighting over resources while the 'bottom' may become a bottomless array of intermediary institutions competing with each other. Equally serious is failure to question the limitations of governments as vehicles for ensuring public safety or, at least, facilitating reduction of disaster risk. DS generally views catastrophic malfeasance of risk governance such as the cases of Hurricane Katrina, Bhopal, Chernobyl and the West African

\footnotetext{
${ }^{5}$ The devil is in the detail, and the way that social protection and other top-down policies are implemented has a good deal to do with whether dependency is a side effect. See, for example Shepherd et al. (2011).
} 
Ebola epidemic as failures of 'good governance' that can be corrected by new laws, policies and procedures. But are there limits to risk governance reform?

Some authors think there are. Charles Perrow argued in his book, Normal Accidents (1999) that failures are inevitable in complex, tightly coupled systems. He revisited that theme in the post 9-11 era (Perrow 2011). Ulrich Beck has a similar view, expressed in the 1992 English translation of Risikogesellschaft (1986). Risk Society argues that ecological modernization is an impossible project of advanced capitalist society based on technology whose failures may provoke 'fixes' that in turn are increasingly complex and prone to failure. In Beck's words (2008: 6):

In risk societies, the consequences and successes of modernization become an issue with the speed and radicality of processes of modernization. A new dimension of risk emerges because the conditions for calculating and institutionally processing it breaks down...

Jasanoff (1994: 2) is convinced that Bhopal and other technological disasters are not 'mishaps' because they open up 'windows to previously unsuspected weaknesses in the social matrix surrounding the technology'. Government ineptitude in the face of Hurricane Katrina was partly due to massive shifts in funding priorities for public safety and organizational changes in FEMA following the September 11, 2001 terror attacks (Tierney 2006). Regarding Ebola, MSF's general director, Christopher Stokes, said in that organization's report (MSF 2015): 'For the Ebola outbreak to spiral this far out of control required many institutions to fail, and they did, with tragic and avoidable consequences'. Joanne Liu, MSF's international president wrote: 'This Ebola response was not limited by lack of international means but by a lack of political will to rapidly deploy assistance to help communities' (MSF 2016). So, too, evidence shows that less dramatic, small and moderate hazards are made into disasters by chronic, widespread, even systemic institutional failure. For example, Güiza et al. (2016) show how clientelism and cartelism in Mexican politics increase vulnerability to flash flooding in a peri-urban locality.

\section{Distance Vision}

\section{From 'DRR' to 'DRC'}

Over the past 50 years, DS research has helped to move disaster policy and practice from a reactive stance to an increasingly proactive one. Progressively disaster risk management involving blue light services, emergency medicine and surgery, shelter management and other coordinated logistics and finance took on the character of more holistic disaster risk reduction (DRR). The latter used planning, legislation and regulations, economic incentives, engineering and public education to reduce exposure, vulnerability, damage and loss from natural hazards and other potentially damaging events. 
In the US it was Florida's 1992 Hurricane Andrew that catalyzed institutionalization of DRR (or 'mitigation' in US terminology). ${ }^{6}$ The need for both vertical and horizontal integration was recognized in a state of Florida report on the 1992 disaster (Huffington Post 2012), words that would be repeated in variations following Hurricane Katrina in 2005, further evidence that DRR is not easy and is a work in progress (Washington Post 2006). The 1992 report stated:

The lack of adequate preparation by our community and our state was obvious. Even more
obvious was the total lack of coordination that existed between the various disaster relief
agencies after the hurricane had passed. No one was in charge. No one knew what to do.
There was no plan. As a result, a large segment of our community that had been reduced to
a 'third world' existence remained that way.

DS has made many contributions to unraveling the complexities of DRR and its application at local/municipal, sub-national, national and international scale. A challenge for DS in the immediate future is to identify obstacles to even greater degrees of comprehensive and integrated risk governance in a post-2015 world, where there is a need and opportunity to plan, program and monitor action on a renewed and expanded set of sustainable development goals (SDGs), actions to adapt to climate change and continued action to reduce disaster risk (Davies et al. 2009; Gaillard and Mercer 2013; Aitsi-Selmi and Murray 2015; Kelman et al. 2015).

Even more demanding a challenge for DS is to clarify conceptually and to document empirically the process of disaster risk creation (DRC) - the shadow, hidden and silent counterpart of the watchword, 'disaster risk reduction' (Lewis and Kelman 2012). Preliminary studies have shown DRC to be the result of much normal, routine economic activity (Wisner 2003; Wisner et al. 2004; Pelling et al. 2011). Unregulated changes in rural and urban land use or changes that escape scrutiny of regulators expose people and assets to coastal storms, landslides and flooding as well as exposure to industrial explosions and toxic contamination of air and water.

The UN's biennial reports on disaster risk have focused attention on the role of global finance and direct foreign investment in risk creation through resource extraction, energy and other megaprojects and property development (UNISDR 2013, 2015b; Lavell and Maskrey 2014). The use of financial power in a starkly divided world means that many investment decisions increase the disaster risk of ordinary people while reaping profits for a few (Sassen 2014). Drawing on C. Wright Mills (1959), Wisner et al. (2004: 33) wrote that the audience for their book on the causes of vulnerability to natural hazards includes those with power who create risk and may not even be aware that they are doing so. Benson (2012: 664) insists that mainstreaming disaster risk into economic development means taking stock of how

\footnotetext{
${ }^{6}$ While most of the world has adopted the UN's term, 'disaster risk reduction', the US continues to use FEMA's earlier term, 'mitigation'. This has two unfortunate consequences. Firstly, 'mitigation' is more difficult to translate into other languages. Secondly, subsequent development of the pair of terms, 'climate change adaptation' and 'climate change mitigation' adds further potential for confusion.
} 
economic development policies, programs and projects affect vulnerability to natural hazards.

Not only do specific developments displace urban and rural people, who often must find a way to live in more hazardous land and cityscapes, but financial power is also destroying the web of life (Moore 2015). The poor depend on biological resources in a more direct way, and a recent World Bank study demonstrates yet again that consequences of climate change will fall heaviest on the poor (World Bank 2016). Just to take one example, consider the fires that consumed large swaths of Indonesia's remaining forest in 2015 and the illegal logging and burning that lies behind this environmental disaster (The Guardian 2015).

Lewis and Kelman identify a number of ways that disaster risk is created by business-as-usual social, political and economic transactions (2012).

- Environmental degradation

- Discrimination

- Displacement

- Impoverishment

- Self-seeking public expenditure

- Denial of access to resources

- Corruption.

Radically transformative approaches to globalized patterns of consumption and unlimited, destructive economic growth include delinking and downsizing scenarios. A set of research questions DS has not yet taken up includes the risk and risk governance implications of localization: for example, depending more on locally produced and processed food and local energy sources. Would local or regional selfreliance create new risks? Could famine result if the local food system failed or would winter heating emergencies ensue if there were problems with local renewable energy systems? Such questions need to be asked, but a main obstacle to such critical inquiry is what Castree et al. (2014: 763) refer to as 'stunted conception of "human dimensions" at a time when the challenges posed by GEC [Global Environmental Change] are increasing in magnitude, scale and scope'.

\section{Through a Glass Darkly}

A lot is being made in the early twenty-first century of 'the dark horizon of the future' in Christophe Bouton's (2013: 77) dramatic phrase. Terrorism, accelerating climate change, pandemics (SARS, for example) and epidemics that threatened to become pandemic (Ebola, MERS, Zika) all fuel a discourse replete with gloomy metaphorical treatment of uncertainty and surprise. 'Opacity' is my personal favorite because it fits with the optical metaphor I have been using throughout this essay.

However, is this current work on uncertainty addressing anything fundamentally new? As Beck (2008: 4) remarked, 'Threat and insecurity have always been among the conditions of human existence'. These conditions have been recognized and 
reflected upon since antiquity. There are words in the ancient Sanskrit language that span a range of meanings associated with uncertainty: ambiguity, dilemma, doubt, suspense, risk and peril (Apte 1890: 1088). Buddhism has taught for millennia that 'the root of suffering is resisting the certainty that no matter the circumstances, uncertainty is all we truly have' (Chödrön 2008: xvii-xviii). The Tao Te Ching, a principle text of Taoism, teaches courage in the face of uncertainty and danger (http://divinetao.com/dt_73_courage.htm):
Courage expressed through daring
is likely to lead to death
Courage restrained with caution
will continue the journey of life ...
Sometimes it helps
Sometimes it harms
whether decided early or late
by mathematics, chance
or a mark on a slate
The sage understands the way...

Chance and uncertainty, personified as the goddess Fortuna was understood to be capable of dashing human aspirations and plans in Renaissance Italy. The strength or courage (virtù) of Machiavelli's prince is the cultural antithesis of character of Taoism's courageous sage. The prince is decisive and daring in the face of uncertainty. Earlier heroes in ancient Greek literature were seen to have flaws that make them vulnerable, their lives contingent and uncertain (McCoy 2013).

What is new is humanity's ability to intervene in processes small and large. We are able to change the world at the quantum scale and more crude, yet tiny, scale of nano-engineering and manipulation of genomes. The consequences and side effects of this dexterous manipulation are, indeed, uncertain. Some worried that when the Large Hadron Collider was powered up and used, the earth might be gobbled up in a black hole (CERN 2016). Concerns with genetic engineering led to a spate of legislation in Europe that enshrined the precautionary principle. ${ }^{7}$ Humanity's manipulation of the entire biosphere and atmosphere as well as our massive impact on the hydrosphere open a new chapter in earth history, the Anthropocene (Crutzen and Stoermer 2000), the consequences of which are not clear. Stephen Hawking,

\footnotetext{
${ }^{7}$ The precautionary principle as defined by UNESCO and the EU: 'When human activities may lead to morally unacceptable harm that is scientifically plausible but uncertain, actions shall be taken to avoid or diminish that harm. Morally unacceptable harm refers to harm to humans or the environment that is (1) threatening to human life or health, or (2) serious and effectively irreversible, or (3) inequitable to present or future generations, or (4) imposed without adequate consideration of the human rights of those affected. The judgement of plausibility should be grounded in scientific analysis. Analysis should be ongoing so that chosen actions are subject to review. Uncertainty may apply to, but need not be limited to, causality or the bounds of the possible harm. Actions are interventions that are undertaken before harm occurs that seek to avoid or diminish the harm. Actions should be chosen that are proportional to the seriousness of the potential harm, with consideration of their positive and negative consequences, and with an assessment of the moral implications of both action and inaction. The choice of action should be the result of a participatory process' (EU 2016).
} 
before his death, and others at the Centre for Existential Risk at Cambridge University focused on a set of risks in part driven by such human technological (over)reach (CER n.d.):

- Biological and biotechnological risks

- Artificial intelligence

- Molecular nanotechnology

- Extreme climate change

- Systemic risks and fragile networks.

Writings and reflections on opacity and uncertainty are important contributions to our understanding of risk, especially as they broaden the scope of research to include a wider range of technological, social and biological hazards. However, here too DS's distant vision can be distorted if uncorrected by a political lens. True, the sudden explosion of Zika virus cases in Brazil was unexpected (McNeil et al. 2016). But viewed in the context of the political ecology of health and disease in Brazil, the causal cascade or progression of vulnerability responsible is not at all opaque (Wisner et al. 2012). Brazilian law professor Debora Diniz puts it like this (Diniz 2016):

Lost in the panic about Zika is an important fact: The epidemic mirrors the social inequality of Brazilian society. It is concentrated among young, poor, black and brown women, a vast majority of them living in the country's least-developed regions. The women at greatest risk of contracting Zika live in places where the mosquito is part of their everyday lives, where mosquito-borne diseases like dengue and chikungunya were already endemic. They live in substandard, crowded housing in neighborhoods where stagnant water, the breeding ground for disease-carrying mosquitoes, is everywhere. These women can't avoid bites: They need to be outdoors from dawn until dusk to work, shop and take care of their children. And they are the same women who have the least access to sexual and reproductive health care.

Lack of a political lens distorts DS' distance vision in another way. Governments are entirely capable of using fear to discipline and to control their populations. DS should ask to what degree at least some of the discourse of existential risk, surprise and uncertainty is the twenty-first century version of a tactic of discipline and control that Foucault $(1988,1990)$ called bio-politics and dates from the eighteenth century (Baumann 2006; Grove 2013; Lorey 2015). Some have argued that the US and other governments have used public fear of terrorism to justify a huge expansion of the national security state, 'securitization' (Altheide 2006; Furedi 2009; Warner 2013; Walklate and Mythen 2015) and the rise of what Hewitt (2013) calls 'the security-industrial-state'. In the process, local, state and national scale capacity to prevent and to respond to other 'normal' hazards (floods, coastal storms, earthquakes, landslides and wildfires; industrial fires and explosions; toxic spills) has decreased (Tierney 2006; Perrow 2011; Hewitt 2013), not to mention decreased visibility of smaller scale, everyday disasters. In another context, research on climate change policy in Tanzania as it affects the ability of small farmers to adapt spontaneously to climate change shows a similar kind of manipulation by government. Appeal to 'the climate imperative' is being used by the Tanzanian state to justify land grabs, displacement of pastoralists and mega-projects that displace yet 
others and as an excuse for malfeasance and failed rural development plans (Smucker et al. 2015).

\section{(Failing) to Govern Risk}

New forms of global risk governance have been proposed and much discussed by legal experts, philosophers and political scientists (Innerarity and Solana 2013). Ulrich Beck developed his earlier ideas of the risk society (1986) into a systematic exposition of what he called world risk society $(1999,2008)$. By this he refers to border-transcending risks that no state can cope with alone and to which globalized capital will not respond (Beck 2013). The latter point is not surprising in light of the argument I made earlier that globalized capital is responsible for a good deal of risk creation. Indeed, some have argued that capitalism makes profit from catastrophes (Klein 2008; Loewenstein 2015).

The response to such an unprecedented set of challenges is, for Beck and others, new forms of global governance, in which 'boundaries, basic rules, and basic distinctions are renegotiated - not only between national and international spheres, but also between global business and the state, transnational civil society movements, supra-national organizations, and national governments and societies' (2013: 15). Beck (2008) considers as civilizational risks climate change, transnational terrorism, global health problems and financial market instability. Such challenges require cooperation among states and, according to Beck and others, are leading to a cosmopolitan model of risk governance (Jáuregui 2013). Researchers and practitioners in the humanitarian community have come to similar conclusions (Donini et al. 2008). In the words of a group that has launched a new resource platform for humanitarian planning (Planning from the Future 2016), there is a need to:

Lay out the reasons and evidence for why the [humanitarian] system needs to fundamentally change, and ... suggest measures that will make it fit for an ever more complex, uncertain and, in many respects, unknown, future. In so doing, ...draw upon the lessons of the past, capture the rapidly changing landscape of the present, and propose ways to prepare for a world in which the types, dimensions and dynamics of threats that produce humanitarian needs will increase - in some instances, exponentially.

There are, indeed, precedents for global cooperation to manage serious transboundary challenges. Nobel laureate Elinor Ostrom, developed a notion of polycentic governance of natural resources that has had some success in managing the world's 200 or so international rivers (Myint 2012) and other transborder resources (Ostrom 1990, 2010). Other examples of global cooperation in confronting problems include atmospheric ozone destruction, pandemics and proliferation of nuclear weapons. Those urging cosmopolitanism (and polycentrism) might also draw encouragement from the long survival of the Antarctic treaty and agreement on the non-military uses of outer space. However, against this evidence of cooperation 
there is the slow and questionable progress on agreeing on an effective international response to climate change and partial, halting progress on the law of the sea (especially as regards mining the deep sea bed) and patchy enforcement of the ban on trade in endangered species, not to mention trafficking in people, arms, drugs and money laundering.

A reality check for theoreticians of a cosmopolitan architecture for risk governance is the poor record of the UN's organization devoted to disaster risk reduction. The UNISDR's Hyogo Framework for Action for Disaster Reduction (HFA) was supposed to be implemented by the 168 states that signed up to it in 2005. But the UNISDR's efforts to monitor compliance relied entirely on self-reporting by the nation states, and it has been shown that these reports exaggerated success (GNDR $2009,2011,2013)$. While there has been development of political will to implement risk reduction in some countries, and some development of capacity to do so, progress has been uneven (Lavell et al. 2012; UNISDR 2015b).

The role of national systems for social protection in disaster risk reduction is underdeveloped (Peacock and Prater 2012), and researchers and policy makers do not fully understand how rapid urbanization in most of the world interacts with disaster risk (Johnson 2012). Meanwhile welfare reform and the policy of austerity are being implemented in many countries around the world and threaten social protection (Ortiz et al. 2011) while urbanization continues to accelerate. The combined impact of austerity and unplanned urbanization holds the potential for unprecedented disaster impacts.

Can the political lens help to sharpen the focus of DS on forms of global risk governance that are desirable, possible or likely? Beck believes that confronting global risks such as climate change, terrorism, pandemic disease and financial crisis will provoke a radical transformation among the stakeholders within the modern nation state as well as among those states. He writes (2013: 15-16):

Action strategies, which global risks open up, overthrow the order of power, which has formed in the neoliberal capital-state coalition: global risks empower states and civil society movements because they reveal new sources of legitimation and possibilities of action for these groups of actors; on the other hand, they disempower globalized capital because the consequences of investment decisions and externalizing risks in financial markets contribute to creating global risks...

The notion of radical change or transformation has become common in the discourse of climate change and disaster risk reduction. For example, Tschakert et al. (2013) provide an account of iterative decision-making, action and reflection that they believe has the potential for such structural change. They propose a process that begins and ends (and begins again) with vulnerability assessment that involves households and communities as agents and beneficiaries in partnership with administrators and professionals at various scales. Such a dialogical, decentralized approach is just one of a vast number of similar action research and activist interventions taking place across planet Earth (Wisner 2016). They have in common a conversation with and among people about their own capabilities in the face of change and threats. They involve a locally based process that can raise consciousness and 
begin a process of social and political mobilization. The result can be a demand on the state and on corporations for transformation, and at times the circumvention of the state and market as groups of people create their own alternatives (Hardt and Negri 2004; Gibson-Graham 2005; McCarthy 2005; El-Khoury 2015).

DS is well placed to study the role and function of social movements that are likely to be the bottom-up counterpart of top-down forms of cosmopolitan, polycentric global risk management. These social movements work across both public and private spheres and may be described as 'rhizomic': being diffuse, non-hierarchical, heterogeneous and operating without an organizing center (Jones et al. 2014: 130; Deleuze 1976; Deleuze and Guattari 1987), taking advantage of social media (for example see This Changes Everything https://solutions.thischangeseverything.org/ and Peaceful Uprising http://www.peacefuluprising.org/). Such social movement networks have been studied by political ecology using actor-network theory (Latour 1987; Law and Hassard 1999), but not in the context of DS (Holifield 2009; Blok 2010). There is a good deal that is not known about these movements for climate justice, corporate industrial safety and public health accountability, financial sector reform, citizen and faith community support for migrants and refugees. As I argued above, all of these issues bear directly, and some indirectly, on our understanding and management of disaster risk. How do these movements originate? How are they maintained? How and when are they likely to become bureaucratized and rigid? How do they interact with governments and with more traditional, hierarchical nongovernmental organizations (INGOs)? In some cases, such as in Nepal, civil society, INGOs, bilateral and international donors have more or less completely taken the place of the national government in promoting and building capacity for disaster preparedness over the past 20 years (Jones et al. 2016).

\section{Conclusions and Recommendations}

Over the past 50 years disaster studies has made great contributions to our understanding of risk. Human beings, their perceptions, knowledge and behavior, groups and networks have been brought into focus in the causal nexus that determines vulnerability, exposure, risk, and risk reduction. Individual and group recovery has also benefited from DS research, as has the development and critique of disaster risk planning and management approaches. Time has seen an increase in the scope of DS focus that now embraces a comprehensive set of hazards: natural (earthquake, flood), social (terrorism, violent conflict), biological (epidemics, biodiversity decline), technological (pollution, industrial accidents), and climate change related. Impressive as these contributions have been, they have been limited by insufficient attention to issues of power at micro and macro scales. The foregoing has identified a number of distortions in DS's near and distant vision that have resulted from a lack of such a political lens. Wearing bifocals that would correct these problems of 
vision, DS could dramatically increase its relevance to the next 15 years $^{8}$ of common effort to reduce disaster risk and support people in recovery.

\section{Acceptance and Support for the Following Recommendations Would Constitute a Start}

1. DS research could focus more on the potential of all human beings to be full partners in identifying, assessing, managing and reducing risk. DS could identify ways to open up political and social space within which local residents can assess their own vulnerability to the hazards to which they give priority and develop capabilities to reduce risk while pursuing other goals. The action research task would be for DS to help facilitate going beyond merely understanding and acting on risk messages from experts. Local residents would feel empowered to work out their own paths to greater security in ways that are consistent with their cultures and aspirations (Oliver-Smith 2015). DS has already contributed to understanding obstacles to active partnership in risk management by some groups: women, children and youth, older people, and people living with disability (Wisner et al. 2012), but more could be done.

2. DS research could address institutional failures at multiple scales, looking especially at the role of corruption and neo-liberal management strategies such as public private partnerships and outsourcing of regulatory and other government functions. There is much that DS research could do to support the trend toward monitoring, evaluation and upwards as well as downwards accountability within the UN and international systems, in governments and among the varied institutions making up civil society. In the first instance, a common inter-agency system for monitoring the roll out of all of the post-2015 international initiatives would be of great benefit (Hasan 2015). From 2015 governments and other stakeholders will face the challenge of implementing agreements that have emerged from international negotiations on disaster reduction, climate change adaptation, development finance, sustainable development goals (SDGs) and the global humanitarian system. Implementation needs to be monitored, and given the interconnections among all these issues, a comprehensive and integrated approach seems logical. In addition, recalling my earlier remarks about topdown and bottom-up planning, perception and knowledge, monitoring should include the views and experiences of ordinary people and give them considerable weight, not just lip service.

3. DS research could complement attention given to disaster risk reduction (DRR) with work on disaster risk creation as a function of business-as-usual economic, social and political transactions. DS could also help to anticipate the risk implications of localization and delinking strategies some have proposed as an

\footnotetext{
${ }^{8}$ The Sendai Framework of Action to Reduce Disaster Risk, agreed by 193 countries in 2015, is scheduled to run until 2030 (UNISDR 2015a), hence the figure of 15 years.
} 
alternative to unlimited globalized economic growth. My argument above was not that DRR is mistaken, rather that it is one-sided. One does not want to throw baby out with bath water. DS achieved a good deal by focusing attention on many of the processes that hold the key to risk reduction. In particular, early research showed clear connections among poverty, environmental destruction and disaster vulnerability (Cuny 1983; Blaikie and Brookfield 1987; Varley 1995; Blaikie et al. 1994). Nevertheless, this work remained trapped by the very word 'development.' Rodney (1972) turned development discourse on its head with his book, How Europe Underdeveloped Africa, using the word 'underdeveloped' as verbal adjective, not a noun describing a condition. DS has to ask what is going on outside the conventional domain of 'development' and 'environment' that contributes to risk creation.

4. DS research could help to anticipate new and complex risks and to assess critically alerts and risk management messages by governments and other interest groups, especially those that make claims about the role of opacity and uncertainty. Most members of the broad community of practice I defined earlier as 'disaster studies' do not have the technical background to develop or to assess critically models that begin to hint at nasty conjunctures in the future. In any case, most risk scenarios are only extrapolations of events that have already occurred: combinations such as civil conflict and epidemic disease (e.g. Boko Haram's refusal to allow children in northern Nigeria to be vaccinated) or earthquake, tsunami and nuclear reactor melt down (e.g. Tohoku and Fukushima Dai Ichi). The contribution of DS lies more in detailed study of the relationship among science, government and society: the organization of the scientific labor process and how it is influenced by ideology and political pressure, how questions about future threats are generated, how results are communicated, and how they are received and interpreted.

5. DS research could study the new wave of social movements and networks emerging around the world as a response to global environmental change and concerns with an expanded notion of food security and climate change that take a human rights and justice perspective (Alkon and Norgaard 2009; Pettit 2009; Gottlieb and Joshi 2010; Bond 2012). What is their potential for moving governments and corporations to change? How do these movements differ from mobilizations of people seen in the past in post-disaster situations (Olson and Gawronski 2003)? Can they have a role in monitoring disaster risk reduction efforts (as in recommendation number 3 , above)? Can social movements be both active partners and watchdogs during the roll out of the array of post-2015 programs and reforms? If so there may be a greater chance for effective climate governance and management of other trans-boundary risks as well as for social protection and advancement of the capabilities of marginal groups and the poorest people. 


\section{References}

Aitsi-Selmi, A., \& Murray, V. (2015). The Sendai framework: Disaster risk reduction through a health lens. Bulletin of the World Health Organisation, 93, 362.

Alkon, A., \& Norgaard, K. (2009). Breaking the food chains: An investigation of food justice activism. Sociological Inquiry, 79(3), 289-305.

Altheide, D. (2006). Terrorism and the politics of fear. Latham: Alta Mira Press.

Andersen, M., \& Woodrow, P. (1989). Rising from the ashes: Development strategies in times of disaster. Boulder: Westview.

Anderson, M. (2011). Disaster writing: The cultural politics of catastrophe in Latin America. Charlottesville: University of Virginia Press.

Apte, V. S. (1890). The practical Sanskrit-English dictionary. Poona: Shiralkal. https://books. google.com/books?id=sflKAQAAMAAJ\&pg=PA1088\&lpg=PA1088\&dq=sanskrit+idea+of + uncertainty\&source=bl\&ots=lRvpQUDZoa\&sig=Z2s7CEVL8DweOj_owzUhdLXL3xE\&hl= en\&sa=X\&ved=0ahUKEwjh6qHyi_HKAhXDWT4KHdCNCRUQ6AEILjAE\#v=onepage\&q $=$ sanskrit $\% 20$ idea $\% 20$ of $\% 20$ uncertainty $\& \mathrm{f}=$ false

Arnstein, S. (1969). A ladder of citizen participation. Journal of the American Institute of Planners, 35(4), 216-224.

Bartle, P. (2012). Community empowerment collective. http://cec.vcn.bc.ca/

Bates, F., \& Peacock, W. (1987). Disaster and social change. In R. Rynes, B. DeMarchis, \& C. Pelanda (Eds.), Sociology of disaster (pp. 291-330). Milan: Franco Angelis.

Baumann, Z. (2006). Liquid fear. Cambridge: Polity.

Beck, U. (1986). Risikogesellschaft: Auf dem Weg in eine andere Moderne. Frankfurt: Suhrkamp Verlag.

Beck, U. (1992). Risk society: Towards a new modernity. Beverley Hills: Sage.

Beck, U. (1999). World risk society. London: Polity.

Beck, U. (2008). World at risk. London: Polity.

Beck, U. (2013). Living in and coping with a world risk society. In D. Innerarity \& J. Solana (Eds.), Humanity at risk: The need for global governance (pp. 11-18). New York: Bloomsbury.

Benson, C. (2012). Economic development policy and disaster risk. In B. Wisner, JC Gaillard, \& I. Kelman (Eds.), The Routledge handbook of hazards and disaster risk reduction (pp. 664 676). London: Routledge.

Birkmann, J. (Ed.). (2013). Measuring vulnerability to natural hazards (2nd ed.). Tokyo: United National University Press.

Blaikie, P., \& Brookfield, H. (1987). Land degradation and society. London: Methuen.

Blaikie, P., Cannon, T., Davis, I., \& Wisner, B. (1994). At risk: Natural hazards, people's vulnerability and disasters. London: Routledge.

Blok, A. (2010). Topologies of climate change: Actor-network theory, relational-scalar analytics, and carbon-market overflows. Environment and Planning D: Society and Space, 28(5), 896-912.

Bolin, R., \& Stanford, L. (1998). The Northridge earthquake: Community-based approaches to unmet recovery needs. Disasters, 22(1), 21-38.

Bond, P. (2012). The politics of climate justice: Paralysis above, movement below. Durban: University of KwaZulu-Natal Press.

Bouton, C. (2013). The dark horizon of the future: Opacity, disaster and responsibility. In D. Innerarity \& J. Solana (Eds.), Humanity at risk: The need for global governance (pp. 77-86). New York: Bloomsbury.

Burton, I., Kates, R., \& White, G. (1978). The environment as hazard. New York: Oxford University Press.

Castree, N., Adams, W., Barry, J., Brockington, D., Büscher, B., Corbera, E., Demeritt, E., Duffy, R., Neves, K., Newell, P., Pellizzoni, L., Rigby, K., Robbins, P., Robin, L., Rose, D., Ross, A., Schlosberg, D., Sörlin, S., West, P., Whitehead, M., \& Wynne, B. (2014). Changing the intellectual climate. Nature Climate Change, 4(August), 763-768. 
CER (Centre for the Study of Existential Risk). (n.d.). Emerging risks from technology. Cambridge University. http://cser.org/emerging-risks-from-technology/

CERN. (2016). The safety of the LHC. Press release. Geneva: CERN Press Office. http://press. web.cern.ch/backgrounders/safety-lhc

Chambers, R. (1999). Whose reality counts? Putting the first last (2nd ed.). Rugby: Intermediate Technology Development Group.

Chambers, R. (2002). Participatory workshops: A sourcebook of 21 sets of ideas and activities. London: Routledge.

Chambers, R. (2008). Revolutions in development inquiry. London: Routledge.

Chödrön, P. (2008). Comfortable with Uncertainty: 108 teachings on cultivating fearlessness and compassion. Compiled and edited by E. Sell. Boston: Shambala.

Cooke, B., \& Kothari, U. (2001). Participation: The new tyranny? (4th ed.). London: Zed.

Crutzen, P., \& Stoermer, E. (2000). Anthropocene. Global Change Newsletter, 41(May), 17-18.

Cuny, F. (1983). Disasters and development. New York: Oxford.

Davies, M., Oswald, K., \& Mitchell, T. (2009). Climate change adaptation, disaster risk reduction and social protection. In A. Stuart \& DAC Network on Poverty Reduction (Eds.), Promoting pro-poor growth: social protection (pp. 201-217). Paris: OECD.

Deleuze, G. (1976). Rhizome. Paris: Editions de Minuit.

Deleuze, G., \& Guattari, F. (1987). A thousand plateaus: Capitalism and schizophrenia. Minneapolis: University of Minnesota Press.

Diniz, D. (2016, February 8). The Zika virus and Brazilian women's right to choose. New York Times. http://www.nytimes.com/2016/02/08/opinion/the-zika-virus-and-brazilian-womensright-to choose.html?emc=edit_ty_20160208\&nl=opinion\&nlid=11158846\&_r=0

Donini, A., Fast, L., Hansen, G., Harris, S., Minear, L., Mowjee, T., \& Wilder, A. (2008). The state of the humanitarian enterprise: Humanitarian agenda 2015 - Final report. Medford: Feinstein International Center, Tufts University.

Drabek, T. (1987). Emergent structures. In R. Dynes, B. De Marchi, \& C. Pelanda (Eds.), Sociology of disasters: Contribution of sociology to disaster research (pp. 190-259). Milan: Franco Angeli.

Dynes, R. (1970). Organized behavior in disaster. Lexington: D.C. Heath.

El-Khoury, A. (2015). Globalization and social justice. London: Routledge.

Enarson, E. (2001). What women do: Gendered labor in the Red River Valley flood. Global Environmental Change Part B: Environmental Hazards, 3(1), 1-18.

Enarson, E., \& Fordham, M. (2001). From women's needs to women's rights in disasters. Environmental Hazards, 3(3), 133-136.

EU. (2016). The precautionary principle. The Precautionary Principle Website. http://www.precautionaryprinciple.eu/

Foucault, M. (1988). The care of the self. New York: Vintage.

Foucault, M. (1990). The uses of pleasure. New York: Vintage.

Freire, P. (1973). Pedagogy of the oppressed: Ethnics, democracy and civic courage. New York: Seabury Press.

Furedi, F. (2009). Invitation to terror: The expanding empire of the unknown. London: Bloomsbury.

Füssel, H.-G., \& Klein, R. (2006). Climate change vulnerability assessments: An evolution of conceptual thinking. Climate Change, 75(3), 301-329.

Gaillard, J. C., \& Mercer, J. (2013). From knowledge to action: Bridging gaps in disaster risk reduction. Progress in Human Geography, 37(1), 93-113.

Gibson, T., \& Wisner, B. (2015, October 28-29). Poster presented at INQUIMUS Workshop, Challenges in $\mathrm{Q}^{2}$ methodologies to acquire and integrate data for the assessment of risk, vulnerability and resilience, Bolzano, Italy. https://www.flickr.com/photos/iied/17042356106

Gibson-Graham, J. (2005). Surplus possibilities: Postdevelopment and community economies. Singapore Journal of Tropical Geography, 26, 4-26. 
GNDR (Global Network of Civil Society Organisations for Disaster Reduction). (2009). Views from the Frontline 2009. Clouds but little rain. Teddington: GNDR. http://www.gndr.org/learning/resources/gndr-publications/item/1468-views-from-the-frontline-2009-report.html.

GNDR (Global Network of Civil Society Organisations for Disaster Reduction). (2011). Views from the Frontline. 2011: If we do not join hands. Teddington: GNDR. http://www.globalnetwork-dr.org/programmes/views-from-the-frontline/vfl-2011.html.

GNDR (Global Network of Civil Society Organisations for Disaster Reduction). (2013). Views from the Frontline 2013: Beyond 2015. Teddington: GNDR. http://www.gndr.org/learning/ resources/gndr-publications/item/1464-views-from-the-frontline-2013-report.html.

Gottlieb, R., \& Joshi, A. (2010). Food justice. Cambridge, MA: MIT Press.

Grineski, S., Bolin, B., \& Boone, C. (2007). Criteria air pollution and marginalized populations: Environmental inequity in metropolitan Phoenix, Arizona. Social Science Quarterly, 88(2), 535-554.

Grove, K. (2013). Adaptation machines and the parasitic politics of life in Jamaican disaster resilience. Antipode, 46(3), 611-628.

Guggenheim, M. (2014). Introduction: Disaster as politics - Politics as disaster. The Sociological Review, 62(S1), 1-16.

Güiza, F., Simmons, P., Burgess, J., \& McCall, M. (2016). Chronic institutional failure and increased vulnerability to flash floods in the Cuenca Altadel Rio Lerma, Mexico. Disasters, $40(1), 112-133$.

Hardt, M., \& Negri, A. (2004). Multitude: War and empire in the age of empire. New York: Penguin Press.

Harvey, P., \& Lind, J. (2005). Dependency and humanitarian relief: A critical analysis. HPG Research Report. London: ODI. www.odi.org/resources/docs/277.pdf

Hasan, M. (2015, July 8). Sendai monitoring and support SDGs. UNISDR News Archive. https:// www.unisdr.org/archive/45067

Hewitt, K. (2012). Culture, hazard and disaster. In B. Wisner, JC Gaillard, \& I. Kelman (Eds.), The Routledge handbook of hazards and disaster risk reduction (pp. 85-96). London: Routledge.

Hewitt, K. (2013). From hazards to 'the security-industrial complex': Civil defense and enterprise in modern disaster culture. Keynote lecture I, cultures and disasters II: Exploring the links between disasters and culture(s): Preparedness, response, policies. Interdisciplinary conference. Erlangen. 11.07-12.07.2013.

Hirschman, A. (1970). Exit, voice, and loyalty: Responses to decline in firms, organizations, and states (Vol. 41, Issue. 4, New ed., pp. 637-658). Cambridge, MA: Harvard University Press.

Holifield, R. (2009). Actor-network theory as a critical approach to environmental justice: A case against synthesis with urban political ecology. Antipode, 41(4), 637-658.

Huffington Post. (2012, August 12). Hurricane Andrew: 20 facts you may have forgotten. Huffington Post. http://www.huffingtonpost.com/2012/08/21/20-facts-hurricane-andrewanniversary_n_1819405.html

Innerarity, D., \& Solana, J. (Eds.). (2013). Humanity at risk: The need for global governance. London: Bloomsbury.

Jasanoff, S. (1986). Risk management and political culture. New York: Russell Sage.

Jasanoff, S. (1994). Introduction: Learning from disasters. In S. Jasanoff (Ed.), Learning from disaster: Disaster management after Bhopal (pp. 1-21). Philadelphia: University of Pennsylvania Press..

Jáuregui, G. (2013). A new political order for the twenty-first century. In D. Innerarity \& J. Solana (Eds.), Humanity at risk: The need for global governance (pp. 123-142). New York: Bloomsbury.

Johnson, C. (2012). Urban and regional planning and disaster. In B. Wisner, J. C. Gaillard, \& I. Kelman (Eds.), The Routledge handbook of hazards and disaster risk reduction (pp. 641652). London: Routledge.

Jones, M., Jones, R., Whitehead, M., Wood, M., Dixon, D., \& Hannah, M. (2014). An introduction to political geography: Space, place, politics. London: Routledge. 
Jones, S., Oven, K., \& Wisner, B. (2016). A comparison of the governance landscape of earthquake risk reduction in Nepal and the Indian State of Bihar. International Journal of Disaster Risk Reduction, 15, 29-42.

Kelman, I., \& Mercer, J. (2014). A knowledge integration tool for disaster risk reduction including climate change. In A. Lopez-Carresi, M. Fordham, B. Wisner, I. Kelman, \& JC Gaillard (Eds.), Disaster management: International lessons in risk reduction, response and recovery (pp. 287-299). London: Earthscan.

Kelman, I., Gaillard, JC, \& Mercer, J. (2015). Climate change's role in disaster risk reduction's future: Beyond vulnerability and resilience. International Journal of Disaster Risk Science, 6(1), 21-27.

Klein, N. (2008). The shock doctrine: The rise of disaster capitalism. New York: Picador.

Latour, B. (1987). Science in action: How to follow scientists and engineers through society. Milton Keynes: Open University Press.

Lavell, A., \& Maskrey, A. (2014). The future of disaster risk management. Environmental Hazards, 13(4), 267-280.

Lavell, A., Gaillard, JC, Wisner, B., Saunders, W., \& van Niekerk, D. (2012). National planning and disaster. In B. Wisner, JC Gaillard, \& I. Kelman (Eds.), The Routledge handbook of hazards and disaster risk reduction (pp. 617-629). London: Routledge.

Law, J., \& Hassard, J. (Eds.). (1999). Actor network theory and after. Oxford: Blackwell and the Sociological Review.

Leiss, W., \& Chociolko, C. (1994). Risk and responsibility. Montreal: McGill-Queens University Press.

Lewis,J.,\&Kelman,I.(2012,June21).Thegood,thebadandtheugly:Disasterriskreduction(DRR)versusdisasterriskcreation(DRC).PLOSCurrentDisasters.http://currents.plos.org/disasters/article/ the-good-the-bad-and-the-ugly-disaster-risk-reduction-drr-versus-disaster-risk-creation-drc/

Loewenstein, A. (2015). Disaster capitalism: Making a killing out of catastrophe. London: Verso.

Lorey, I. (2015). State of insecurity. London: Verso.

Mascarhenas, A., \& Wisner, B. (2012). Politics: Power and disaster. In B. Wisner, JC Gaillard, \& I. Kelman (Eds.), The Routledge handbook of hazards and disaster risk reduction (pp. 48-60). London: Routledge.

Maskrey, A. (1989). Disaster mitigation: A community based approach. Oxford: Oxfam.

McCarthy, J. (2005). Commons as counterhegemonic projects. Capitalism, Nature, Socialism, 16, 9-24.

McCoy, M. (2013). Wounded heroes: Vulnerability as a virtue in ancient Greek literature and philosophy. Oxford: New York.

McNeil, D., Romero, S., Tavernise, S. (2016, February 7). Medical mystery with a global reach. New York Times. http://www.nytimes.com/2016/02/07/health/zika-virus-brazil-how-it-spreadexplained.html

Mercer, J. (2012). Knowledge and disaster risk reduction. In B. Wisner, JC Gaillard, \& I. Kelman (Eds.), The Routledge handbook of hazards and disaster risk reduction (pp. 97-108). London: Routledge.

Mills, C. W. (1959). The sociological imagination. New York: Oxford University Press.

Monbiot, G. (2015, October 30). Indonesia is burning. So why is the world looking away? The Guardian. http://www.theguardian.com/commentisfree/2015/oct/30/ indonesia-fires-disaster-21st-century-world-media

Moore, J. (2015). Capitalism and the web of life: Ecology and the accumulation of capital. London: Verso.

MSF (Medecins sans Frontieres). (2015). Ebola: Pushed to the limit and beyond. http://www.msf. org.uk/article/ebola-pushed-to-the-limit-and-beyond-msf-report

MSF (Medecins sans Frontieres). (2016). Ebola: Outbreak over in West Africa; world must learn lesson for future, says MSF. http://www.msf.org.uk/article/ ebola-outbreak-over-in-west-africa-world-must-learn-lesson-for-future-says-msf 
Munzara, A., \& Benn, N. (2014). Guidance on citizen voice and action for resilience and livelihood programming. Federal Way: World Vision.

Myint, T. (2012). Governing international rivers: Polycentric politics in the Mekong and the Rhine. Cheltenham: Edward Elgar.

Nigg, J., \& Tierney, K. (1993). Disasters and social change: Consequences for community construct and affect. Disaster Research Center preliminary paper no. 195. University of Delaware, Disaster Research Center.

Nussbaum, M. (2011). Creating capabilities: The human development approach. Cambridge, MA: Harvard University Press.

Oliver-Smith, A. (2015). Conversations in catastrophe: Neoliberalism and the cultural construction of disaster risk. In F. Krüger, G. Bankoff, T. Cannon, B. Orlowski, \& L. Shipper (Eds.), Cultures and disasters: Understanding cultural framings and disaster reduction (pp. 37-52). Geneva: IFRC.

Olson, R., \& Gawronski, V. (2003). Disasters as critical junctures: Managua, Nicaragua 1972 and Mexico City 1985. International Journal of Mass Emergencies, 21, 3-35.

Ortiz, I., Chai, J., \& Cummins, M. (2011). Austerity measures threaten children and poor households: Recent evidence in public expenditure in 128 developing countries. New York: UNICEF. http://www.unicef.org/socialpolicy/index_59872.html.

Ostrom, E. (1990). Governing the commons: The evolution of institutions for collective action. Cambridge, MA: Cambridge University Press.

Ostrom, E. (2010). Beyond markets and states: Polycentric governance of complex economic systems. American Economic Review, 100(3), 641-672.

Peacock, W., \& Prater, C. (2012). Social protection and disaster. In B. Wisner, JC Gaillard, \& I. Kelman (Eds.), The Routledge handbook of hazards and disaster risk reduction (pp. 687 697). London: Routledge.

Pelling, M., \& Dill, K. (2010). Disaster politics: Tipping points for change in sociopolitical regimes. Progress in Human Geography, 34(1), 21-37.

Pelling, M., Manuel-Navarrete, D., \& Redclift, M. (Eds.). (2011). Climate change and the crisis of capitalism: A chance to reclaim self, society and nature. London: Routledge.

Perrow, C. (1999). Normal accidents: Living with high risk technologies (Updated ed.). Princeton: Princeton University Press.

Perrow, C. (2011). The next catastrophe: Reducing our vulnerabilities to natural, industrial, and terrorist disasters. Princeton: Princeton University Press.

Pettit, J. (2009). Climate justice: A new social movement for atmospheric rights. IDS Bulletin, 35(3), 102-106.

Planning from the Future. (2016). Planning from the future. Tufts University/Kings College London/Overseas Development Institute. http://www.planningfromthefuture.org/about.html

Quarantelli, E. (1954). Nature and conditions of Panic. American Journal of Sociology, Social Problems 8(1) 60, 267-275.

Quarantelli, E. (1960). Images of withdrawal in disasters: Some basic misconceptions. Social Problems, 68-79.

Quarantelli, E., \& Dynes, R. (1972). When disaster strikes: It isn't much like what you've heard and read about. Psychology Today 9, (February), 67-70.

Rodney, W. (1972). How Europe underdeveloped Africa. London: Bogle-L'Ouverture Publications.

Sassen, S. (2014). Expulsions: Brutality and complexity in the global economy. Cambridge, MA: Harvard University Press.

Scott, J. (1987). Weapons of the weak: Everyday forms of peasant resistance. New Haven: Yale University Press.

Scott, J. (2010). The art of not being governed: An anarchist history of upland Southeast Asia. New Haven: Yale University Press.

Sen, A. (2005). Capabilities and human rights. Journal of Human Development, 6(2), 151-166. 
Shepherd, A., Wadugodapitiya, D., \& Evans, A. (2011). Social assistance and the 'Dependency Syndrome'. Policy paper no. 22, January. London: Chronic Poverty Research Centre. http://www. chronicpoverty.org/publications/details/social-assistance-and-the-dependency-syndrome/ss

Smit, B., Burton, I., Klein, R., \& Wandel, J. (2000). An anatomy of adaptation to climate change and variability. Climate Change, 45(1), 223-251.

Smucker, T., \& Wisner, B. (2008). Changing household responses to drought in Tharaka, Kenya: Persistence, change, and challenge. Disasters, 32(2), 190-215.

Smucker, T., Wisner, B., Mascarhenas, A., Munishi, P., Wangui, E., Sinha, R., Weiner, D., Bwenge, C., \& Lovell, E. (2015). Differentiated livelihoods, local institutions, and the adaptation imperative: Assessing climate change adaptation policy in Tanzania. Geoforum, 59, 39-50.

Stallings, R., \& Quarantelli, E. (1985). Emergent citizen groups and emergency management. Public Administration Review, 45, 93-100.

Thompson, M. (2012). Civil society and disaster. In B. Wisner, J. C. Gaillard, \& I. Kelman (Eds.), The Routledge handbook of hazards and disaster risk reduction (pp. 723-736). London: Routledge.

Tierney, K. (2006). The Red Pill. Understanding Katrina: Perspectives from the social sciences. Social Science Research Council. http://understandingkatrina.ssrc.org/Tierney/

Tierney, K. (2014). The social roots of risk: Producing disasters, promoting resilience. Stanford: Stanford Business Books.

Tschakert, P., St. Clair, A., Lamadrid, A., \& van Oort, B. (2013). Conceptual and methodological reflections on vulnerability assessments: A comprehensive focus on inequality and capacity for change. Climate and Development, 5(4), 340-350.

UNISDR. (2013). Global assessment of disaster risk reduction 2013. Geneva: UNISDR. https:// www.unisdr.org/we/inform/publications/33013

UNISDR. (2015a). Sendai framework for disaster reduction. Geneva: UNISDR. http://www.org/ we/coordinate/sendai-framework

UNISDR. (2015b). Global assessment of disaster risk reduction 2015. Geneva: UNISDR. http:// www.preventionweb.net/english/hyogo/gar/2015/en/home/GAR_2015/GAR_2015_1.html

Varley, A. (Ed.). (1995). Disasters, development and environment. London: Wiley.

Walklate, S., \& Mythen, G. (2015). Contradictions of terrorism: Security, risk and resilience. London: Routledge.

Warner, J. (2013). The politics of 'catastrophization'. In D. Hilhorst (Ed.), Disaster, conflict and sin crisis (pp. 76-94). London: Routledge.

Washington Post. (2006, February 23). Federal response to hurricane Katrina: Lessons learned. http://www.washingtonpost.com/wpdyn/content/article/2006/02/23/AR2006022300531.html

Wenger, D., \& Parr, A. (1969). Community functions under disaster conditions. Research report 4. Columbus: Disaster Research Center, Ohio State University.

White, H. (2008). Identity and control: How social formations emerge (2nd ed.). Princeton: Princeton University Press.

Wisner, B. (1988). Power and need in Africa. London: Earthscan.

Wisner, B. (1995). Bridging 'expert' and 'local' knowledge for counter-disaster planning in urban South Africa. GeoJournal, 37(3), 335-348.

Wisner, B. (2003). Changes in capitalism and global shifts in the distribution of hazard and vulnerability. In M. Pelling (Ed.), Natural disaster and development in a globalizing world (pp. 43-56). London: Routledge.

Wisner, B. (2010). Climate change and cultural diversity. International Social Science Journal, $61,131-140$.

Wisner, B. (2016). Vulnerability as concept, model, metric and tool. Oxford Research Encyclopedia of Natural Hazard Science. In S. Cutter (Ed.) The Oxford Research Encyclopedia of Natural Hazard Science. New York: Oxford University Press. 
Wisner, B., \& Haghebaert, B. (2006, February 2-3). Fierce friends/friendly enemies: State/civil society relations in disaster risk reduction. Paper presented at the ProVention Consortium Forum 2006, Bangkok.

Wisner, B., Blaikie, P., Cannon, T., \& Davis, I. (2004). At risk: Natural hazards, people's vulnerability and disasters (2nd ed.). London: Routledge.

Wisner, B., Gaillard, J. C., \& Kelman, I. (Eds.). (2012). The Routledge handbook of hazards and disaster risk reduction. London: Routledge.

World Bank. (2016). Shock waves. Washington, DC: World Bank.

Ben Wisner is a visiting professor at the Institute for Risk and Disaster Reduction of University College London. He is co-author of two editions of At Risk: Natural Hazards, People's Vulnerability and Disasters (1994 and 2004) and directed the United Nations University programme, "The Geography of Social Vulnerability in Megacities" (1997-2001), producing the co-edited collection Disaster Risk Reduction: Cases from Urban Africa (2009). Dr. Wisner is also the co-editor of The Routledge Handbook of Hazards and Disaster Risk Reduction (2012) and Disaster Management: International Lessons in Risk Reduction, Response and Recovery (2013). Currently he is a coeditor of the Oxford Encyclopedia of Natural Hazard Governance. 